\title{
1. NGOs and global politics
}

\section{Aynsley Kellow and Hannah Murphy-Gregory}

Any examination of NGOs must commence with a discussion of definitions. 'NGO' is an abbreviation for 'Non-Governmental Organisation', that much is clear; but what does such a term include, and what does it not cover? Does it apply to organisations active within nation-states or just to international NGOs (INGOs)? How does it differ from other terms such as 'Non-State Actor' (NSA) or 'Civil Society Organisation' (CSO)?

We have chosen in the volume to focus only on the international level. Though we acknowledge that 'NGO' is a term often applied to groups active at the level of domestic politics, such groups are conceptually and functionally different. Much of relevant domestic political activity is well covered by the term 'interest group', and there is a vast literature on that phenomenon. (Admittedly, the rules for granting consultative status in the United Nations system were relaxed to permit nationally based groups, which complicates matters.)

As Thomas Davies shows in this volume (see also Davies, 2014), there have been international NGOs for at least a couple of centuries, and they played prominent roles in important campaigns such as the abolition of slavery, the granting of suffrage to women and the prohibition of alcohol (Nadelmann, 1990). Perhaps one of the best-known NGOs, the Red Cross, dates back to 1863. The International Labour Organization (ILO), associated with the League of Nations, was a tripartite intergovernmental organisation (IGO) that provided for membership by employer and labour organisations as well as governments. Bob Reinalda explores the history of NGOs in IGOs in Chapter 3.

The term 'non-governmental organisation' did not emerge in common usage until the foundation of the United Nations in 1945. Article 71 of the UN Charter made provision for a consultative role for organisations which were neither governments nor member states, and the term 'international NGO' was first defined in resolution $288(\mathrm{X})$ of the UN Economic and Social Council (ECOSOC) adopted on 27 February 1950. An INGO was defined as 'any international organization that is not founded by an international treaty'. The history of consultative status for NGOs at the UN is set out by Peter Willetts (1996) in Chapter 2 of The 
Conscience of the World: The Influence of Non-Governmental Organisations in the UN System, and he brings these insights up to date in his chapter for this volume (Chapter 4).

The UN General Assembly itself was keen to engage in consultations with NGOs and pushed ECOSOC to adopt 'suitable arrangements' for the World Federation of Trade Unions (WFTU), the International Co-operative Alliance and other NGOs. The system of consultative status was soon formalised with the establishment by ECOSOC of a Committee on NGOs, but had first to decide what type of organisation might be granted consultative status.

The NGO Committee recommended that an NGO should be concerned with matters within the compétence of ECOSOC; that its aims should be consistent with the UN Charter; that it should represent a substantial proportion of the people in its field; and that it should speak for its members through authorised representatives. A sensitive issue was how national organisations should be regarded, given that they might speak with a different voice to that of their host member states, and it was decided that NGOs based in one country could be accepted, but only if they were not members of an international NGO or if they were able to offer 'special experience'. The American Federation of Labour (AFL) was given early recognition, but lost its consultative status in March 1950 when the International Confederation of Free Trade Unions (ICFTU) was granted consultative status because the AFL was a member of this organisation. It was later reaffirmed that single-country NGOs could be accepted only after the relevant government had been consulted. In practice, very few national organisations were granted consultative status, however, until the mid-1990s, when the restriction had been undermined somewhat, particularly on environmental matters. This occurred via the device of 'action networks' (in the Basel and Climate Conventions, for example) whereby the network would gain consultative status and national organisations would use the network as a kind of flag of convenience to participate in deliberations.

The explosion in international NGOs has perhaps been greatest with environmental NGOs (or ENGOS). The website of the UN Framework Convention on Climate Change, for example, records about 1,600 NGOs as having been admitted as observers. The relaxation of restrictions on national organisations has increased overall numbers, with the Climate Action Network now joined not just by the main national NGOs, but also by a myriad of groups of unknown size, provenance and affiliation. To what extent many of these are representative of anybody is questionable. To give one example, one group that was admitted is the Green Institute Limited, then based in our home town (Hobart). It is a 'green think tank' 
that only seemed to have one person associated with it prior to 2013, a former staffer for the leader of the Greens Party who had made several donations to that party. The group has sponsored numerous 'Green Schools' to train Green Party candidates, including such features as a comedian speaking on 'the end of the world'. In Chapter 6, Elizabeth Bloodgood addresses the complex task of attempting to quantify NGOs.

As the term ENGO in the preceding paragraph suggests, this explosion of numbers has stimulated a need for a taxonomy to make sense of the numerous kinds of INGOs. This has given rise to numerous acronyms: BINGO (Business international NGO); LINGO (Labour INGO); DINGO (Development INGO); GONGO (Government-organised NGO); DONGO (Donor organised NGO); TANGO (Technical assistance NGO); and MANGO (Market advocacy NGO). In Chapter 5 Anna Vakil discusses the issues in attempting to classify NGOs and suggests a framework for doing so. The BINGO acronym might seem somewhat out of place, as the term NGO is most commonly applied to social, human rights and environment groups; but it may also be applied to business groups, at least since ECOSOC granted consultative status to the International Chamber of Commerce in October 1946. Of course, transnational corporations (TNCs), literally speaking, are international non-governmental organisations but individual TNCs are never regarded as NGOs. When they take part in UN events, they are described as being from 'the private sector'.

Simply from considerations of length, this volume will deliberately not cover BINGOs (except for some passing references); and neither will it attempt to cover those organisations that are not avowedly 'public good' in orientation - whether that public good purpose be social, development, aid, environment, human rights, gender and so on. We will not devote any attention to terrorist groups such as Al Qaeda, for example, though clearly that organisation would qualify as a non-state actor (but not as an NGO).

The presence of GONGOs in the list above draws attention to questions of independence and accountability, and the relationship between NGOs and nation-states. Nation-states have been known to either help establish NGOs or support those established, and so they are often regarded with a degree of suspicion by other nation-states. NGOs cannot, therefore, be regarded as rising above the world of states - at least not without a degree of scepticism. As Willetts (1996) shows, the granting of consultative status has never been unproblematic, with the tensions of the Cold War spilling over into the process and concerns over numbers evident from an early stage. ECOSOC required joint representation for some pairs of organisations until the mid-1950s, and 
13 women's organisations were grouped until 1969 in a 'Liaison Committee' to act as the consultative body when they shared views, but were allowed to operate separately when their views differed.

NGOs can be supported in a variety of ways, not always involving direct funding. Some NGOs, for example, benefit by being contracted to deliver programs that are supported by the UN or by member states making voluntary contributions, sometimes even specifying the NGO they wish to be granted the contract. Even if not dependent on such contracts, NGOs are overwhelmingly formed in the global North and tend therefore to reflect the values and priorities of those societies rather than those of the global South; even if they are championing the causes of the South, they are at risk of doing so with a Northern gloss.

For these reasons, ENGOs (in particular) have often been regarded with a degree of suspicion in the South, and have been since the emergence of global environmental issues at about the time of the Stockholm Conference in 1972, a time of some considerable neoMalthusianism and talk of triage and 'lifeboat ethics' that alarmed the South. 'Sustainable development' was the linguistic compromise designed to resolve these conflicts, but they led to some restrictions on ENGOs after the expansion of access engineered by Maurice Strong at the 1992 Rio Conference when the G-77 ensured that the UN Commission on Sustainable Development (CSD) was accountable, via the ECOSOC, to the General Assembly, a forum they controlled (Sandbrook, 1997). There are other examples of states limiting participation by NGOs, including the use of 'non-groups' considering 'non-papers' at Kyoto while developing the eponymous Protocol, thereby excluding registered NGOs which would otherwise have been provided with papers and able to participate in official contact groups. One of us (Aynsley Kellow) explores NGOs in the climate regime in Chapter 11.

In addition to the possibility that NGOs might sometimes be used as stalking horses by nation-states, there are other ways in which their activities might not measure up to the standard, commonly held, that because they set out to perform good deeds, they do not require critical scrutiny.

In 2002 the UN Refugee Agency (UNHCR) and Save the Children UK released the findings of a joint investigation of sexual violence and the exploitation of refugee children in West Africa. The investigation reported evidence of 'extensive' sexual exploitation of refugee children in Liberia, Guinea and Sierra Leone, much of it attributed to workers locally employed by national and international NGOs as well as by UN agencies, including UNHCR itself. These workers reportedly used 'the very 
humanitarian aid and services intended to benefit the refugee population as a tool of exploitation' (UNHCR, 2002).

Another kind of issue was demonstrated in Indonesia in the aftermath of the Boxing Day tsunami of 2004. With the death toll in Aceh province then estimated to be 110,000 , and an estimated 600,000 rendered homeless, many aid NGOs mounted an assistance effort; but they were regarded with suspicion by local Muslim leaders, who accused them of seeking to convert locals to Christianity. The greatest concern centred on the arrival of Western Christian groups with records of aggressive preaching, with one American group proposing to fly hundreds of local children to a Christian orphanage. Din Syamsuddin, head of the Indonesian Council of Clerics, criticised this, stating that any attempt to spread religion under the cover of aid was wrong (Burke, 2005).

NGOs have entrenched their place in global governance in two major ways. First, they provide services of value to IGOs by lobbying national governments to support international policy measures and reporting on a state's non-compliance. In both instances they help overcome the limitation (formal in the case of UN agencies) on IGOs becoming involved in the domestic affairs of member states (Kellow, 2000). Second, where a developing nation-state does not have the resources or technical capacity to adequately put its interests forward in international arenas, NGOs can act as 'resource enhancers' (see Tuerk, 2003; Stairs and Taylor, 1992: 128). This is especially evident at the World Trade Organization (WTO), where NGOs have provided developing nations with valuable research and analysis on trade policy matters (Murphy, 2010). However, this outcome is dependent upon the NGOs and developing states sharing a common goal or interest, which is not always the case. For example, at the World Bank, NGOs have frequently campaigned against infrastructure projects that may have benefited developing nations.

It appears that NGOs have achieved greater success at the World Bank, because of the dominant position of the US, than they have been able to achieve in either accessing or influencing broader international economic policy arenas such as the WTO. The NGO International Rivers, had a leading role in campaigns by NGOs to persuade the World Bank to limit funding for hydro-electric development and it was able to persuade the US (among other powerful donor countries) to use its influence within the Bank (Fox and Brown, 1998). Pressure from global NGO networks, supported by the success of International Rivers at the domestic level in the US led to the establishment of the World Commission on Dams, resulting in an end to investment in large dams by the Bank for the next decade (Dingwerth, 2005; Reinicke, 1999-2000). 
This observation seems to hold for other similar arenas, such as the Inter-American Development Bank (IDB) where with the Camisea gas pipeline in Peru, the only (but crucial) vote against the project from the 46 member governments on the board came from the United States, in response to an NGO campaign (Mallaby, 2004), and with individual projects - not always with the best outcome. For example, the Qinghai dam project in China saw a winning coalition formed in the US Congress among environmentalists, human rights activists and right-wing Senator Jesse Helms, who was quick to seize an opportunity to criticise China. NGOs were able to secure cuts in Congressional appropriations to the World Bank's soft-loan window in 1999 of \$220 million to deny its ability to fund the project; but this simply resulted in China withdrawing its request for funding and proceeding with the project from its own financial resources, freed totally from the social and environmental disciplines the Bank would have imposed (Mallaby, 2004). Hannah Murphy-Gregory explores NGOs and global economic policy institutions in Chapter 9.

The importance of the domestic route for NGOs seeking to influence global governance should not be underestimated, for it is significant not just where there are hegemons (such as the US in the World Bank), but even where influence is more dispersed and fluid. One of the greatest successes for NGOs in global governance has been the adoption of a moratorium on whaling in the International Whaling Commission (IWC), which saw the transformation of a regime to regulate the harvest of whales into one to prohibit the same (Mitchell, 1998). This result reflected not just the success of campaigns in former whaling states such as the UK, US and Australia, but also the sponsorship by NGOs to membership of many new states that had previously had no interest or involvement in whaling, the accession of several land-locked states and even the representation of developing countries such as the Seychelles, Panama, St Lucia, Antigua and Barbuda by NGO personnel (Peterson, 1992). An NGO participant described this as a coup d'état (Wilkinson, 1989) and, contra perspectives emphasising the importance of epistemic consensus, the outcome relied upon NGOs and parties they were able to mobilize (such as the United States) exerting influence despite the advice of the IWC Scientific Committee, leading its chairman to resign (Epstein, 2005). This is an extreme case of NGOs gaining influence because of the relative weakness of developing countries, as it goes well beyond the provision of technical support and translation that can 'buy' influence with states unable to meet participation costs (Stairs and Taylor, 1992). 
The UN is not the only IGO, of course, and NGOs have also clustered around others, including the International Financial Institutions (IFIs) such as the World Bank, the International Monetary Fund (IMF) and the General Agreement on Tariffs and Trade (GATT) and its secretariat even prior to its formalisation into the WTO in 1995. These IGOs have not typically been as welcoming as the UN, often eschewing engagement completely in the belief that any social or environmental concerns should inform national views expressed by their membership, although the World Bank and the WTO particularly have since the 1990s sought to engage with civil society in various ways. As the Organisation for Economic Co-operation and Development (OECD) discovered in the 1990s, rather secret methods of operation and a sense of exclusion can build suspicion and mistrust.

\section{CLASSIFYING NGOs AND THEIR INFLUENCE}

It is useful to categorise NGOs functionally - those that are operational and involved in the delivery of programs, and those that are involved in advocacy or campaigning. Operational NGOs implement projects. Operational NGOs seek to mobilise financial resources, materials and volunteers to deliver localised programs, such as environment, health, aid or development assistance. They might raise their own funds, or obtain grants or contracts from governments or private or public organisations to raise money for projects. Operational NGOs might be relief-oriented or development-oriented, and they might be religious or secular, and be public or private.

Campaigning or advocacy NGOs seek to affect global policy. They must mobilise their supporters and plan and organise demonstrations and events that will ensure their cause receives media attention. They typically deal with issues of human rights, women's rights and children's rights, and usually try to raise awareness of issues and policy responses and build knowledge by lobbying, issuing press statements and organising activist events.

These two functions are, of course, not mutually exclusive. NGOs that are prominent in delivering programs will often, by virtue of their reputation deriving from the successful conduct of that activity, be able to speak with authority, and thus influence debates over global policy issues. As noted earlier, Anna Vakil takes up these issues in Chapter 5. 


\section{NGOs AND AGENDA-SETTING}

NGOs are often formed to change the status quo, and governments are often focused on existing policy issues; so NGOs are always prominent in the process of getting new items onto the agenda, of moving existing ones further up the agenda of public discourse or the agenda of governments or UN deliberative bodies. Activities within nation-states can help affect the position of states within the global policy process, and such activities can range from protest action through to more conventional lobbying. Use of the media is often important; but so too is the generation of knowledge-based material drawing attention to the existence of some problem and its possible solution. This activity does not always entail grass-roots political activity: Greenpeace, for example, uses skilled professional staff to engage in risky activities such as climbing chimney stacks and draping banners to create publicity.

Rather than involving members in mass participation protest, Greenpeace solicits donations from supporters and undertakes action on behalf of supporters who donate to it - a model sometimes referred to as 'slacktivism'. The pressure to secure publicity sometimes leads groups such as Greenpeace to overstep the bounds of conduct considered acceptable. For example the group erected a banner on the sensitive World Heritage listed Nazca Lines in Peru in December 2014 to publicise its support for renewable energy in relation to the 20th Conference of the Parties to the Framework Convention on Climate Change taking place in Lima. It had similarly made itself unpopular with the Antarctic Treaty parties by establishing and operating a 'World Park Base' in Antarctica between 1987 and 1992 (considered to be in breach of the spirit of the Treaty by some, resulting in a withdrawal of the logistical and emergency support usually provided to other expeditions). The selective adherence by NGOs to international law and governance potentially weakens the moral authority of NGOs seeking action by way of international law or global policy. However it is frequently the case that such behaviour is deemed by supporters to be an acceptable campaigning method to highlight the significance of a normative goal.

\section{NGOs AND POLICY FORMULATION}

Global policy decisions are typically developed in negotiating conferences sponsored by the UN or within some other arena such as the World Bank, the WTO or the OECD. But the scope for NGOs to influence these outcomes is limited, and much of their influence stems from their ability 
to shape the positions of national governments that are developed in advance of negotiations. Many NGO activities in international arenas are unlikely to have much impact at all on the outcomes, but will help publicise the position of the NGOs. Often there is only limited provision for statements on behalf of all NGOs. Diplomats are often pressured by NGO representatives at negotiating conferences, but it is unlikely that such pressure alone produces results. As noted earlier, devices such as 'non-groups' considering 'non-papers' can be used deliberately to limit NGO access.

NGOs can affect policy formulation with skilful work in various committees, perhaps drafting suitable language where the opportunity arises; but this requires expertise and the authority that comes from reputation - which may be harmed by engaging in more extreme activities that secure prominent media coverage from the scrum of competing NGOs and national governments. As Michael Lipsky (1968) once pointed out, successful protest requires appealing to four constituencies simultaneously (members, the media, the target and possible third-party alliance partners); but appealing to one may alienate others. The greatest opportunities for NGO influence usually come from acting in concert with a delegation with which it broadly shares positions, as illustrated by the discussion about NGOs in the WTO context. The degree of influence afforded by this type of access is likely to be greater when the delegation lacks resources, such as that of a nation from the South, for which the costs of effective participation might be prohibitive. NGOs that render such assistance may be more likely to gain opportunities to influence the negotiating position of the delegation.

NGOs will often attempt to pressure governments to sign a policy instrument (convention, treaty or protocol) at a conference or to ratify it later. This activity is helpful to treaty secretariats, which clearly have an interest in the ratification and entry into force of the instrument on which their very existence depends. The value of these services can translate into influence with treaty secretariats, possibly leading to influence for NGOs in deliberative processes. This is especially the case within the UN system because Article 2(7) of its Charter prevents the United Nations from intervening in matters that are essentially within the domestic jurisdiction of any state, so NGOs can venture where secretariats fear to tread. 


\section{NGOs AND POLICY IMPLEMENTATION}

Article 2(7) of the UN Charter reflects a widespread sensitivity about sovereignty and the possibility that it might be infringed by either other states or IGOs, and it contributes to a problem with implementation and what Arild Underdal describes as the 'vertical disintegration of policy' (see, for example, Hanf and Underdal, 1998). How can implementation be ensured and verified? Any suggestion of IGO involvement is likely to be resisted, but NGOs can generate political pressure by exposing governments' failures to realise implementation of the policy obligations they have accepted. They might generate publicity or information on which legal action might be taken in the European Court of Justice, for example. NGOs can also become involved in policy implementation through program delivery whereby a UN body or other agency or a government might wish to use NGO expertise and experience while distancing themselves from the program for whatever reason.

\section{OUTLINE OF THE BOOK}

This volume is organised into three broad sections. The first covers what are essentially introductory issues. Tom Davies traces the historical development of NGOs, and then Bob Reinalda sets out their place in the history of IGOs. Peter Willetts discusses NGOs at the United Nations, describing the way in which their role as insider participants has evolved over time. Anna Vakil and Elizabeth Bloodgood then deal with issues of classification and quantification, rounding out the introductory section.

The next section focuses on NGOs in specific global policy areas. First, Jutta Joachim looks at NGOs and gender equality. Then follow chapters by: Hartmut Elsenhans and Hannes Warnecke-Berger (development); Hannah Murphy-Gregory (global economic policy institutions); Anja Mihr (human rights); Aynsley Kellow (climate politics); Ainsley Elbra (tax justice); Timothy Doyle (the environment); and Karsten Ronit (consumer associations).

The final section covers some issues with NGOs, as well as the significance of the different arenas and processes found in global politics. Dennis Redeker and Kerstin Martens write on NGOs and accountability. Fred Gale examines the relatively recent development of private governance regimes, in which NGOs feature prominently. Johanna SiméantGermanos provides insights into the phenomenon of NGOs that commence life at the level of the nation-state but then 'go global'. Overwhelmingly, NGOs are formed and flourish in the global 'North', in 
liberal democracies; but they are also emerging in other political systems, and Carolyn Hsu provides some valuable insights into the rise of NGOs in the People's Republic of China. No volume on NGOs today can omit discussion of the particular case of the European Union, and Justin Greenwood performs that task. Philip Fountain and Marie Juul Petersen discuss the important issue of religion and NGOs. Finally, Aynsley Kellow and Hannah Murphy-Gregory explore the participation of NGOs in multi-level, multi-arena governance, including tactics such as forum shopping.

While there are other topics that might have been covered, we are confident that these chapters provide extensive coverage of some of the key issues essential to an understanding of NGOs. They constitute a collection of critical appraisals of most aspects of the field, and should serve as a solid introduction to the research field.

\section{REFERENCES}

Burke, Jason (2005) 'Religious Aid Groups Try to Convert Victims: Muslim Clerics Object as Western Christian Groups Hand out Food and Bibles.' The Guardian, 16 January. www.theguardian.com/world/2005/jan/16/tsunami2004.internationalaidanddevelopment1 (accessed 10 April 2016).

Davies, Thomas (2014) NGOs: A New History of Transnational Civil Society. New York: Oxford: Oxford University Press.

Dingwerth, Klaus (2005) 'The Democratic Legitimacy of Public-Private Rule Making: What Can We Learn for the World Commission on Dams?' Global Governance 11: 65-83.

Epstein, Charlotte (2005) 'Knowledge and Power in Global Environmental Activism.' International Journal of Peace Studies 10: 47-67.

Fox, Jonathan A. and L. David Brown (1998) The Struggle for Accountability: The World Bank, NGOs and Grassroots Movements. Cambridge, MA: MIT Press.

Hanf, Kenneth and Arild Underdal (1998) 'Domesticating International Commitments: Linking National and International Decision-Making' in Arild Underdal (ed.) The Politics of International Environmental Management. Dordrecht: Kluwer.

Kellow, Aynsley (2000) 'Norms, Interests and Environment NGOs: The Limits of Cosmopolitanism.' Environmental Politics 9(3): 1-22.

Lipsky, M. (1968) 'Protest As a Political Resource.' American Political Science Review 62(4): 1144-58.

Mallaby, Sebastian (2004) The World's Banker: A Story of Failed States, Financial Crises, and the Wealth and Poverty of Nations. New York: Penguin.

Mitchell, Ronald B. (1998) 'Discourse and Sovereignty: Interests, Science and Morality in the Regulation of Whaling.' Global Governance 4: 275-93.

Murphy, Hannah (2010) The Making of International Trade Policy: NGOs, Agenda-Setting and the WTO. Cheltenham, UK and Northampton, MA, USA: Edward Elgar Publishing.

Nadelmann, Ethan A. (1990) 'Global Prohibition Regimes: The Evolution of Norms in International Society.' International Organization 44(4): 479-526.

Peterson, M.J. (1992) 'Whalers, Cetologists, Environmentalists, and the International Management of Whaling.' International Organization 46: 147-85. 


\section{Handbook of research on NGOs}

Reinicke, Wolfgang H. (1999-2000) 'The Other World Wide Web: Global Policy Networks.' Foreign Policy 117: 44-57.

Sandbrook, Richard (1997) 'UNGASS Has Run Out of Steam.' International Affairs 73(4): 641-54.

Stairs, Kevin and Peter Taylor (1992) 'Non-Governmental Organisations and the Legal Protections of the Oceans: A Case Study' in Andrew Hurrell and Benedict Kingsbury (eds) The International Politics of the Environment: Actors, Interests and Institutions. Oxford: Oxford University Press, 110-41.

Tuerk, Elisabeth (2003) 'The Role of NGOs in International Governance. NGOs and Developing Country WTO Members: Is There Potential for an Alliance?' in S. Griller (ed.) International Economic Governance and Non-Economic Concerns: New Challenges for the International Legal Order. Vienna and New York: Springer, 169-209.

UNHCR (2002) 'Extensive Abuse of West African Refugee Children Reported.' Press release, 26 February. www.unhcr.org/3c7bf8094.html (accessed 10 April 2016).

Wilkinson, D.M. (1989) 'The Use of Domestic Measures to Enforce International Whaling Agreements: A Critical Perspective.' Denver Journal of International Law and Policy 17: 271-91.

Willetts, Peter (1996) The Conscience of the World: The Influence of Non-Governmental Organisations in the UN System. London: Hurst. 